EZEAH GREGORY,

Department of Mass Communication, University of Nigeria (Nsukka, Nigeria)

e-mail: Gregory.ezeah@unn.edu.ng,ORCID 0000-0002-0998-5251

GEVER VERLUMUN CELESTINE,

Department of Mass Communication, University of Nigeria, Nsukka

e-mail: Encyclopeadia100@gmail.com,ORCID 0000-0003-0618-5352

\title{
LITERARY JOURNALISM IN THE FACE OF GLOBAL FOOD CRISIS: TECHNIQUES ON THE WAY OUT
}

Over the years, world leaders have continued to troubleshoot approaches to combating hunger. Although the increasing hunger appears to be affecting countries in different continents of the world, African countries and part Asia appear to be most hit. This study examines the nexus between literary journalism and combating the global hunger crisis with specific attention to Nigeria. Specifically, the study examined the extent literary journalism can be deployed to combat hunger, the techniques to deploy in using literary journalism to drive government policies on food sufficiency and encourage public participation in agriculture. Literary journalism, though an emerging field, has the potential of promoting agricultural activities and policies that will lead to eventual food security. Literary journalism presents an opportunity through which agriculture can be developed and food security enhanced. Understanding the approaches and techniques of literary journalism for combating global food crisis is a significant contribution to literature in the following ways: First, it will provide newer insights into the role of literary journalism in agricultural development and food security. In the second place, this study contributes to literature by opening a new vista in the study of literary journalism. The International Food Policy Research Institute in collaboration with the Food and Agriculture Organization in its Global Hunger Index grouped Nigeria among countries with a high level of hunger threat, with an index of 25.5 which was categorized as serious hunger threat. Based on the concept of 'breakable rules' by Mark Kramer, the following characteristics of literary journalism stand out: immersion in the story worlds; developing implicit rules (covenants) on accuracy and sincerity; description mainly about everyday, routine events; development of meaning, based on a consistent reaction of readers. This study raises the following researcher questions: To what extent can literary journalism promote food security? What literary journalism techniques can be used to encourage participation in agriculture? What literary journalism techniques can be used to drive government policies and programs in agriculture? A total of 30 respondents provided narratives on the nexus between literary journalism and food sufficiency. A structured interview guide was used as the instrument for data collection while thematic analysis guide was used to analyze the result of study. The result of the semi-structured interview revealed that literary journalism can aid in combating food crisis globally and in Nigeria in particular to a large extent. It was also found that the techniques to be used for combating food crisis include scene-by scene, infotainment, dialogue, subjectivity and accuracy. During the interview sessions, it was discovered that the respondents reported that literary journalism has not been given its pride of place in Nigeria, unlike other parts of the world like the United States of America where it has been in practice since the 1960s. These results were examined with the framework of ACADA model. The model stands for Assessment, Communication, Analysis Design and Action. The model was developed by the United Nations for International Children Emergency Fund. The implications of these results on food sufficiency and the expansion of literature on literary journalism were also discussed.

Keywords: food crisis; hunger; literary journalism; techniques.

\section{Introduction}

The world is currently confronted with the challenge of addressing the global food crisis that has constituted a serious threat to the lives of many people, especially women and children. The growing cases of conflict has made matters worse as there appears to be a significant relationship between conflict and food shortage. Food Security Information Network (Global report..., 2017) in its
2017 report revealed that globally, 108 million people in 2016 were reported to be facing crisis level food insecurity or worse. According to the report, the 2016 figure represents a 35 percent increase in sharp contrast to 2015 in which case the figure was almost 80 million. The global report further paints a picture of the food crisis in different countries of the world. According to the report, conflicts have significantly affected numbers of food insecure people 
in need of urgent assistance in Yemen (17 million); Syria (7.0 million); South Sudan (4.9 million); Somalia (2.9 million); northeast Nigeria (4.7 million), Burundi (2.3 million) and Central African Republic (2 million). The report further notes: "The immediate outlook points to worsening conditions in some locations, with risk of famine in isolated areas of northeast Nigeria, South Sudan, Somalia and Yemen". This report presents a very disturbing global scenario of food crisis.

Food is very essential for human sustenance. Humans cannot survive without good diet. Irregular diet lead to malnutrition which may lead to death. It is doubtful if even the strongest warrior can withstand the onslaught of hunger. This is because hunger is not a respecter of anybody young and old, educated or illiterate, black or white, all humans must eat, without which the issue of existentialism will be raised. Consequently, food security is important because of the following reasons: everybody has to eat, food is a basic human right; food is the basis of a community's economy; people's food system is unduly dependent on distant suppliers; what people see in the grocery store is a vulnerable perfection; people can only control what is close to home; the jurisdiction that cannot feed its people is at the mercy of whoever can; it is vital to preserve the blueprint (capacity, skills and tools to feed ourselves; people are rightly concerned about food-health connections; good food is the basis of health; people in communities are hungry and/or undernourished; inability to pay should not mean hunger; What people eat should not exploit those who produced it and cheap food is too good to be true (Fourteen Reasons..., 2012). Emmanuel Ojo and Peter Adebayo (2012) corroborate that food is life and that it is one of the basic needs of man that must be met.

A study conducted by Kenneth Dahlberg (1998) identified four global threats that have significant negative implications for the food security of cities to include the three different types of incipient population explosions: human, livestock and cars. The second is global warming which is characterized by uncertainty and confusion (Ojo and Adebayo, 1998). The third threat to food security is the loss of biodiversity which constitutes long-term threat to global sustainability. In the fourth place, Kenneth identified the threat of poverty and globalization of injustice as prompting hunger globally. The important thing to note so far is that the world is facing a global hunger threat. This calls for the need to examine ways of addressing it. Literary journalism, though an emerging field, has the potential of promoting agricultural activities and policies that will lead to eventual food security. Examining the place of literary journalism in combating food crisis is particularly pertinent at this time which S. Greenberg and J. Wheelwright (2014) described as a period of difficulty and enormous change characterized by weakened confidence in media institutions as with other sources of authority. The implication of the assertion of S. Greenberg and J. Wheelwright to the current study is that literary journalism presents an opportunity through which agriculture can be developed and food security enhanced. Susan Greenberg (2011: 169) opined that literary journalism has the potential 'to anchor storytelling to a contingent world in a way that is more persuasive and trustworthy'. With the increasing hunger threats despite media campaigns on investments in agriculture, there is the need to consider the literary journalism option. In this regards the assertion of Susan Greenberg is apt:

Literary nonfiction tends to come to the fore in periods of uncertainty because it meets the need, on one hand, to anchor events by documenting them; and on the other, to question official representations by allowing for personal experience. It understands that the extreme privileging of 'authentic' feeling, without an external reality check, can lead to great violence being done to oneself and others, because while emotions are real, they do not exist in vacuum. Authentication is not enough; one also needs verification (Greenberg, 2011: 169).

From the submission above, the researcher had positioned literary journalism as a potent tool for executing campaigns. Norman Sims in his ground-breaking anthology The Literary Journalists (Sims, 1984) observed that literary journalism "demands immersion in complex, difficult subjects. The voice of the writer surfaces to show that an author is at work. Food security is one of such difficult subjects because the threats has continued to linger for too long while literature linking literary journalism and food crisis is substantially scanty.

Understanding the approaches and techniques of literary journalism for combating global food crisis is a significant contribution to literature in the following ways: First, it will provide newer insights into the role of literary journalism in agricultural development and food security. This understanding will shape literature on both literary journalism and agricultural development communication. In the second place, this study will contribute to literature by opening a new vista in the study of literary journalism. This is because it will provide fresh perspectives in the use of literary journalism as campaign tool, not only in food crisis but other areas of human needs like health, commerce, education environment, among others. Theoretically, this study will provide useful insights that will be helpful in testing previous theories and even propounding new ones. Considering that the field of literary journalism is still emerging, more studies are needed to provide evidence on the its importance as an instrument of opinion moulding and attitude change communication.

\section{Nigeria's Food Crisis}

Nigeria is currently facing a serious hunger crisis. It appears that the situation may worsen in the near future. This is evidenced in the declaration of Nigeria's Minister of Agriculture, Audu Ogbe, during the defiance of the Ministry's budget for 2016 before the National Assembly that Nigerians will starve to death by 2050 if nothing is done. According to the Minister, given the current rate of population growth, there was a need to change farming approaches from a seasonal exercise to an all- year round venture (Ekwueme and Gever, 2017). This is in addition to available figures on food security in Nigeria. For instance, the International Food Policy Research Institute in collaboration with the Food and Agriculture Organization (FAO) in its Global Hunger Index (GHI) grouped Nigeria among countries with a high level of hunger threat, with an index of 14.7 (International Food..., 2014). According to the report, higher index scores indicate higher level of hunger threat in rated countries. What this means is that Nigeria's index of 14.7 was an indication of high hunger threat. The latest edition also showed that Nigeria had a higher index score of 25.5 which was categorized as serious hunger threat (International Food..., 2016). Nigeria's food security situation is bad as evidenced in the increasing importation of consumable items. For example, The Governor of Central Bank of Nigeria, Godwin Emefiele, said that Nigerian Government spent N 1.18 trillion between January 2014 and May 2015 on food imports along with toothpicks, textiles and furniture. Top on the import list were rice, fish and milk (Ekwueme and Gever, 2017). These are signs that Nigeria's food crisis has reached an alarming rate, hence the need to consider broader approaches in resolving the problem.

SKHID No. 3 (161) May-June 2019 


\section{Overview of Literary Journalism}

Literary journalism describes the application of literary techniques in journalistic reportage. It entails embellishing truth with subjective techniques. Literary journalism, unlike other literary work, is not fiction because the people involved are real and the events took place. Literary journalism is not journalism in a traditional sense because there is interpretation, a personal point of view, and in most cases, experimentation with structure and chronology. Another essential element of literary journalism is its focus. Rather than emphasizing institutions, literary journalism explores the lives of those who are affected by those institutions (Whitt, 2008). Going by the explanation of literary journalism as explained above, Celestine Gever's book The stolen joy is an example of literary journalism. In the book, Celestine had provided a background information on the conflict between famers and herdsmen in Benue State, detailing concrete instances that took place and proffering solution to the overall conflict, which not only took place is Benue State but other states of the Federation like Enugu, Kogi, among others, Celestine Gever had also presented the role of traditional rulers, security agencies and both the Federal and State governments in the crisis (Gever, 2015). Other examples of literary journalism include "A Hanging" by George Orwell "The San Francisco Earthquake" by Jack London "The Watercress Girl" by Henry Mayhew.

Literary journalism is alternatively called narrative journalism, or creative journalism. It is argued that literary journalism has been a vital genre of American and British journalism since at least the mid-19th century (Hartsock, 2000). Throughout the evolution of literary journalism, different sub-genres have emerged that focus on specific areas of interest, like muckraking, environmentalism, literary sports journalism, personality profiles, and literary war journalism (Kerrane, Yagoda, 1997). It is now time to think of literary agricultural journalism.

Most scholars in attempting to define literary journalism first define what it is not. This is similar to the situation in public relations where attention is paid to what PR is not. Therefore, Literary journalism is not mainstream journalism, as such does not follow the direct language, inverted pyramid, direct quotes, and attribution of traditional hard news, nor the delayed lead, nut graph, and standard transitions between sources and information chunks typical of in mainstream journalism (Kerrane, Yagoda, 1997). What this implies is that literary journalism does not necessarily need to follow the $5 \mathrm{Ws}$ and $\mathrm{H}$ of Who says what? Where? When? Why? and how? Rather, the story is presented in a chronological order, thus, has a beginning, middle and end.

In it basic idea, literary journalism, though completely nonfiction, is concerned first and foremost with narrative. It tells a story, complete with a beginning, middle, and end. Other aspects might include the use of first-person/thirdperson voice, symbolism, metaphor, foreshadowing, immersion reporting, digression, and an intimate voice that is informal, human, frank, and/or ironic (Sims, 2009).

Literary journalism has peculiar characteristics which makes it different from mainstream journalism. Among the features of literary journalism are immersion reporting, complicated structures, character development, symbolism, voice, attention on ordinary people as well as accuracy. Literary journalists recognize the need for a consciousness on the page through which the objects in view are filtered (Nordquist, 2007). In a bid describe the characteristics of literary journalism, Mark Kramer (2017) used the concept 'breakable rules' in an anthology. These rules, according Kramer are:
- Literary journalists immerse themselves in subjects' worlds.

- Literary journalists work out implicit covenants about accuracy and candor.

- Literary journalists write mostly about routine events.

- Literary journalists develop meaning by building upon the readers' sequential reactions.

From the foregoing, literary journalism has its unique characteristics which are summarily embedded in its flexible but truthful style of presentation.

\section{Techniques and of Literary Journalism}

Combating the global food crisis using the instrument of literary journalism requires the adoption of techniques that will effectively communicate the appropriate messages which will engineer positive actions. However, the most controversial technique employed by literary journalists is the subjective approach they take in reporting the events they cover (Stewart, 1997). John Sack (2002) expresses reservation in the ability of objectivity to accurately relate events, arguing instead that a subjective approach to storytelling was the only "kind of journalism with the capacity to get to the real truth. Sims Norman (2009) avers that literary journalism is characterized by the author's voice being present in the narrative and 'immersion reporting' or the practice of spending large amounts of time with the subject, becoming immersed in his or her life for weeks or months, even years. The researcher adds that literary journalism also adopts the techniques long associated only with fiction, such as elaborate structures, characterization, and even symbolism, but with the added requirement of accuracy.' Tom Wolfe (1973) outlines four techniques commonly used by literary journalists: as follows: a) scene-by-scene construction, or depicting people in dramatic scenes as in traditional storytelling; b) complete dialogue as recorded and remembered rather than journalism's selective quotations; c) varying the point of view, and even using third person point of view; and d) status details or the habits, mannerisms, gestures, and so on that distinguish people, societies, and subcultures (31-33). These techniques can as well be used for behavioral and attitude change communication.

Norman Sims (2007) added immersion reporting, accuracy, voice, structure, responsibility and symbolic representation as part of the techniques of literary journalism. Barbara Lounsberry (1990) also identifies four constitutive features of literary journalism. Like Wolfe, Barbara regards 'the scene' as a notable feature of this type of writing. The other three features that Barbara identifies are: documentable subject matter from the 'real' world; exhaustive research; and fine writing in literary prose style. Lounsberry asserts that factually verifiable subject matter and exhaustive research are fundamental to the success of literary journalism, while narrative form grants it artistry, and its polished language 'reveals that the goal all along was literature.' As part of her efforts to expand the techniques of literary journalism, Barbara later included 'simultaneous, sequential, and substitutionary narration; interior monologue; and the artful use of imagery, allusion, humor, and even the pyrotechnics of print itself. From the foregoing, it can be seeing that these techniques were derived from empirical studies nor is there substantial evidence in literature that these techniques have been subjected to any form of empirical test. The situation regarding food crisis even makes it very compelling as there is scanty literature linking literary journalism and food sufficiency. Therefore, this study raises the following researcher questions:

RQ 1: To what extent can literary journalism promote food security? 
RQ 2: What literary journalism techniques can be used to encourage participation in agriculture?

RQ 3: What literary journalism techniques can be used to drive government policies and programmes in agriculture?

The above questions were answered in this study within the theoretical framework of ACADA model. The model stands for Assessment, Communication, Analysis Design and Action. The model was developed by the United Nations for International Children Emergency Fund (Omego, 2014: 147). This model is informed by the fact that influencing or modifying human behavior through communication is a complex process that needs to be planned carefully. The ACADA model is a model designed to bring about development in which attitudinal change is a core element (Omego, 2014: 13).

\section{Methods}

\section{Participants}

The respondents for this study were 30 post graduate students at the University of Nigeria, Nsukka. Of this number, 15 were masters students while 15 were doctoral students. It was decided that post-graduate mass communication students were appropriate for the study because they already have background knowledge of journalism at the undergraduate level and thus, possess the knowledge on literary journalism and how its techniques can be used to combat food crisis.

The participants were selected through a purposive sampling procedure. Purposive sampling is usually the most appropriate technique for qualitative research on the ground that it gives the participants the leeway to express themselves and provide deeper insights. In deciding the number of participants in this study, the researchers relied on John Creswell's (1998) suggested range of 20 and 30 for qualitative studies. Therefore, we recruited the respondents by purposively selecting them after which the purpose of the study was explained to them. Those who agreed signed a consent form.

\section{Data Collection}

To collect data for this study, the researchers used indepth, semi-structured interviews that lasted for $40 \mathrm{mi}-$ nutes to one hour. The interviews were held individually with all the 30 respondents and recorded with the aid of two trained research assistants. All the interviews took place at the University's Postgraduate Hall based on the agreements between the research team and the participants. Each interview began with an explanation of the aim of the study after which the respondents were told to sign a consent form. The interview started with a broadcast question: what techniques should be adopted in using literary journalism to combat hunger threats? We asked follow up questions to gain deeper insights into the subject of enquiry.

\section{Data Analysis}

We used thematic analysis to identify, analyze and report the themes derived from the result of the study. This was done based on what Brawn V. and Clark V. (2006) christen 'patterns' within the data that were gathered. The guide to the phases of conducting the thematic analysis was rigorously followed. These are: familiarity with the data, gathering initial code, searching for themes (vital concepts, explanatory ideas, recurring ideas etc.); reviewing the themes, defining and naming the themes and producing the report inform of illustrative quotes. Therefore, after the interview, all the interviews were transcribed word-to-word to enable the researchers effect the analysis. As a follow up, the researchers identified codes related to the extent can literary journalism promote food security, literary journalism techniques that can be used to encourage participation in agriculture and literary journalism techniques that can be used to drive government production in Nigeria. We then searched for themes under three broad categories: the communication channel, message and the target recipients. As a follow-up, we reviewed our themes and define them under the three broad categories stated earlier before producing the final reports.

\section{Results}

The result of this study showed that the respondents reported that literary journalism can aid in combating food security to a large extent. The respondents reported that literary journalism, when properly used can serve as an effective instrument in promoting agricultural activities. One of the respondents quipped: "literary journalism is the way to go it can to a large extent compliment mainstream journalism in combating hunger." Another respondent said: "Literary journalism has be to given its pride of place when discussing campaigns on food sufficiency". Another respondent averred: "literary journalism is very powerful in attitude change and can to a large extent, help in combating food crisis, not only in Nigeria, but the world at large". We further probed the respondents to determine how literary journalism can help in combating hunger crisis in Nigeria and other countries, and the result showed that most of the participants reported that literary journalism can be used to combat hunger by educating the public on how to be food secure through involvement in agriculture, educating them on agricultural production tips, informing them on new farming techniques, improved crops and other seedlings, how to store their produce as well as farm maintenance techniques.

The result of our study showed that the respondents reported that the techniques for promoting agricultural programs and those for encouraging participation in agriculture were the same. Therefore, it was found that the use of scene-by scene in presenting agricultural messages through literary journalism, emerged as the first technique. According to the respondents, agricultural messages should be presented in scene-by-scene format such that it can stimulate and sustain interest. The respondents reported that the use of infotainment is another good technique for literary journalism. One of the participants said: "An important technique that literary journalists could use is the combination of information and entertainment called infotainment.' The respondents argued that such a technique will entertain the receivers and as well, inform them. This was captured by one of the respondents thus: "infotainment is a vibrant technique that could be used by literary journalists in combating hunger crisis in Nigeria. It simply means, entertain the people while informing."

Another strategy that was found to be very essential for literary journalism was the use of dialogue. The respondents reported that the use of dialogue was another technique that literary journalists could deploy in combating hunger. One of the respondents said: "Dialogue format could be very effective when properly used. Literary journalists, can therefore, use dialogue technique and promote agricultural activities in a manner that that will led to food sufficiency." Other techniques that were found from the study are presenting accurate information as well as complete investigation of the situation at hand before taking any step. In this regard, a participant revealed: "literary journalism cannot succeed without proper understanding of the situation at hand, literary journalists must also 
develop their techniques based on realities and trail-test their techniques." The point is that truth remains a cardinal ingredient in literary journalism. During the interview, some of the respondents reported that even though subjectivity is very key in literary journalism, it does not equal falsehood as doing so will raise credibility concern. In this direction, a respondent revealed: "Although subjectivity is a vibrant tool in literary journalism, it must not be mistaken for falsehood. Subjectivity must not be abused otherwise the aim of literary journalism will be defeated." Another respondents said: "Subjectivity is one technique that every literary journalists must deploy to get the job done. This must be done within the prism of accuracy and truth."

During the interview sessions, it was discovered that the respondents reported that literary journalism has not been given its pride of place in Nigeria, unlike other parts of the world like the United States of America where it has been in practice since the 1960s. The respondents revealed these information spontaneously because there was no question asking them the state of literary journalism in Nigeria. The respondents also reported that most tertiary institutions in Nigeria that offer journalism courses do not pay sufficient attention to literary journalism, a situation that has led to the low application of literary journalism in solving Nigeria's myriads of problems. The participants added that even in the area of conflict resolution where literary journalism has been considerably applied, the situation is not the same in Nigeria.

\section{Discussion of Findings}

This study investigated the techniques for using literary journalism for combating global hunger crisis with specific attention to Nigeria. The result of the semi-structured interview revealed that literary journalism can aid in combating food crisis globally and in Nigeria in particular to a large extent. It was also found that the techniques to be used for combating food crisis include scene-by scene, dialogue, subjectivity, and accuracy. The result of this study is consistent with previous scholars (e.g., Lounsberry, 1990; Sims, 2002; Wolf, 1973) who have examined techniques for literary journalism. The result of this study is in consonance with Sim Norman who provides insights into the techniques of literary journalism in sharp contrast with fiction writers thus:

Unlike fiction writers, literary journalists must be accurate. Characters in literary journalism need to be brought to life on paper, just as in fiction, but their feelings and dramatic moments contain a special power because we know the stories are true. The literary quality of these works comes from the collision of worlds, from a confrontation with the symbols of another, real culture. Literary journalism draws on immersion, voice, accuracy, and symbolism as essential forces (Sim, 2007: 2).

From the assertion above, it can be seen that literary journalists have no option but to stick to the truth. This point is supported by the result of this study. This study has expanded our understanding of techniques for literary journalism by providing empirical support. The result of this study has implications on the ACADA model, implications on combating food crisis as well as implications on the growth of literature on literary journalism. This triad of implications are discussed below:

The result of this study has implications on ACADA mode because the model places emphasis on assessing the situation on ground before packaging communication messages. Our result suggest that literary journalists who are interested in combating hunger crisis must first of foremost, assess the situation on ground and get back- ground knowledge so as to answer questions like: what are the causes of food crisis? Who are the key players that drive these causes? What are variables that drive these causes? How can these causes be addressed? After these questions are answered, the literary journalist will then focus attention on the appropriate techniques that will best drive the message and influence policy direction as well as ensure attitudinal change.

The result of this study has implications on food security because it suggests that combating food crisis through communication initiatives can effectively be done through the use of literary journalism techniques. It thus, goes to show that any efforts geared towards combating food crisis should incorporate literary journalism techniques.

Finally, this result has implications on the advancement of literature on literary journalism because it has expanded the scope of literature by including agriculture and food security as areas that literary journalism can cover. With this result, therefore, this study has opened a new vista in the study of literary journalism.

\section{Conclusion/Recommendations}

In this study, we investigated the techniques for using literary journalism for combating hunger and promoting agricultural activities. Based on our findings, we conclude that literary journalism can be a useful tool for enhancing food security to a large extent. We also conclude that literary journalism techniques that can be used for promoting food security through improvements in agriculture are sceneby-scene, dialogue, accuracy and objectivity. This understanding is very essential especially at a time when global leaders are battling to stem the rising hunger waves. Although Nigeria is facing serious hunger threats occasioned by the Boko Haram crisis in north east Nigeria, the farmer-herdsmen conflict in north central and other parts of Nigeria, the situation is not exclusive in Nigeria as other countries like Syria, Yemen, South Sudan and Somalia are also facing serious hunger threats. This situation is weighing heavily on other countries as donor agencies are continuously seeking for fund to assist people in these countries. Other countries like South Africa, Pakistan, Kenya, among others may not be as pronounced as Nigeria, Syria, Yemen, South Sudan and Somalia, their situation is not completely cheering. Considering the significant role that literary journalism plays in providing details through thorough investigation, the hunger crisis in Nigeria and other parts of the world challenges the role of literary journalists in the promotion of food security programs. Therefore, the basic contribution of this study is that it has provided evidence based understanding on the techniques for combating the current global hunger crisis. Based on the result of this study, we recommend the following: (a) Literary journalists should engage themselves in combating the hunger crisis in Nigeria and other parts of the world (b) There is need for journalism training institutions in Nigeria to include literary journalism in their curricula. (c) Further studies should examine obstacles to literary journalism practice in Nigeria.

\section{REFERENCES}

Brawn, V. L. and Clark, V. (2006). Using Thematic Analysis in Psychology. Qualitative Research in Psychology, 3: 79.

Creswell, John (1998). Qualitative inquiry and research design: Choosing among five traditions. Thousand Oaks, CA: Sage: 225

Dahlberg, Kenneth (1998). Promoting Sustainable Local Food Systems in the United States. For Hunger-proof Cities Sustainable Urban Food Systems. In: Mustafa Koc, Rod MacRae, Luc J.A. 
Mougeot, and Jennifer Welsh (Eds). Cairo: International Development Centre (In English)

Ekwueme, Anthony and Gever, Celestine (2017). Warning Won't Do It: Analysis of Communication Strategies for Enhancing Food Production in Nigeria. International Journal of Communication, (20), 46 (In English)

Fourteen Reasons Why Food Security is Important (2012). Retrieved from http://bcfsn.org/wp-content/uploads/2012/02/14 reasons-why-food-security-is-important. pdf.

Gever, Celestine (2015). The stolen Joy. Nsukka: University Press. (In English)

Global report on food crisis (2017). Food Security Information Network. Retrieved from http://www.fsinplatform.org/sites/default/ files/resources/files/WFP-0000020391.pdf

Greenberg, Susan (2011). Personal experience, turned outward. Free Associations, 62, 169 (In English)

Greenberg, Susan. \& Wheelwright, J. (2014). Literary journalism: Ethics in three dimensions. Journalism, 15(5), pp. 511 516. (In English)

Hartsock, J. C. (2000). A history of American literary journalism: The emergence of modern narrative form. Amherst: University of Massachusetts Press. (In English)

International Food Policy Research Institute (2016). Global hunger index getting to zero hunger. Retrieved September 22, 2017 from http://ghi.ifpri.org/ (In English)

International Food Policy Research Institute (2014). Retrieved September 10, 2017 from Global hunger index: Challenges of hidden hunger Retrieved from http://www.alliance2015.org/ fileadmin/Texte Pdfs/Text_Documents/GHI_2014/140922_GHI_2014_web.pdf (In English)

Kerrane, K., \& Yagoda, B. (Eds.) (1997). The art of fact: A historical anthology of literary journalism. New York: Simon \& Schuster. (In English)

Kramer, Mark (2017). Breakable Rules for Literary Journalists, Retrieved September 26th, 2017 from http://niemanstoryboard.org/ stories/breakable-rules-for-literary-journalists/ (In English)

Lounsberry, Barbara. (1990). The Art of Fact: Contemporary Artists of Nonfiction. Connecticut: Greenwood Press Inc.

Nordquist, Richard (2007). Literary journalism. Glossary of Grammatical and Rhetorical Terms, Retrieved September 10th, 2017 from https://www.thoughtco.com/what-is-literary-journalism-1691132 (In English)

Ojo, Emmanuel and Adebayo, Peter (2012). Food Security in Nigeria: an Overview. European Journal of Sustainable Development, 1, 2: 199-222. (In English)

Omego, C. U. (2014). An Assessment of the Psychological Aspects of Health Communication among Port Harcourt City Residents. An International Multidisciplinary Journal, Ethiopia. 8, 3.

Sack, John (2002). Operation Anaconda. Esquire, 138, 116123. (In English)

Sims, Norman (1984). The Literary Journalists. US: Ballantine Books (In English)

Sims, Norman (2007). True Stories: A Century of Literary Journalism. Illinois: Northwestern University Press.

Sims, Norman. (2009). The problem and the promise of literary journalism studies. Literary Journalism Studies, 1(1), 7-16. (In English)

Stewart, J. (1997). John Sack. In: A. J. Kaul (Ed.). Dictionary of literary biography: American literary journalists, 1945-1995. Detroit: Gale: pp. 273-282. (In English)

Whitt, Jan (2008). Women in American Journalism: A New History. University of Illinois Press (In English)

Wolfe, Tom (1973). The New Journalism: With An Anthology. New York: Harper, 31-33.

\section{LIST OF REFERENCE LINKS}

Brawn V. L., Clark V. Using Thematic Analysis in Psychology. Qualitative Research in Psychology. 2006. 3: 79.
Creswell John. Qualitative inquiry and research design: Choosing among five traditions. Thousand Oaks, CA: Sage, 1998. $225 \mathrm{p}$.

Dahlberg Kenneth. Promoting Sustainable Local Food Systems in the United States. For Hunger-proof Cities Sustainable Urban Food Systems. In: Mustafa Koc, Rod MacRae, Luc J.A. Mougeot, and Jennifer Welsh (Eds). Cairo: International Development Centre, 1998.

Ekwueme Anthony, Gever Celestine. Warning Won't Do It: Analysis of Communication Strategies for Enhancing Food Production in Nigeria. International Journal of Communication. 2017. 20: 46 .

Fourteen Reasons Why Food Security is Important. 2012. Retrieved from http://bcfsn.org/wp-content/uploads/2012/02/14reasons-why-food-security-is-important.pdf.

Gever Celestine. The stolen Joy. Nsukka: University Press, 2015.

Global report on food crisis, 2017. Food Security Information Network. Retrieved from http://www.fsinplatform.org/sites/ default/files/resources/files/WFP-0000020391.pdf

Greenberg Susan. Personal experience, turned outward. Free Associations. 2011. 62: 169.

Greenberg Susan \& Wheelwright J. Literary journalism: Ethics in three dimensions. Journalism. 2014. 15(5), pp. 511-516.

Hartsock J. C. A history of American literary journalism: The emergence of modern narrative form. Amherst: University of Massachusetts Press, 2000.

International Food Policy Research Institute, 2016. Global hunger index getting to zero hunger. URL: http://ghi.ifpri.org/ (Last accessed: September 22, 2017).

International Food Policy Research Institute, 2014. Retrieved September 10, 2017 from Global hunger index: Challenges of hidden hunger. URL: http://www.alliance2015.org/fileadmin/ Texte_Pdfs/Text_Documents/GHI_2014/140922_GHI_2014web.pdf

The art of fact: A historical anthology of literary journalism / Kerrane K. \& Yagoda B. (Eds.). New York: Simon \& Schuster, 1997.

Kramer Mark. Breakable Rules for Literary Journalists. URL: http://niemanstoryboard.org/stories/breakable-rules-for-literaryjournalists/ (Last accessed: September 26th, 2017)

Lounsberry Barbara. The Art of Fact: Contemporary Artists of Nonfiction. Connecticut: Greenwood Press Inc., 1990.

Nordquist Richard. Literary journalism. Glossary of Grammatical and Rhetorical Terms, 2007. URL: https://www.thoughtco.com/what-is-literary-journalism-1691132 (Last accessed: September 10th, 2017)

Ojo Emmanuel and Adebayo Peter. Food Security in Nigeria: an Overview. European Journal of Sustainable Development. 2012. 1, 2: 199-222.

Omego C. U. An Assessment of the Psychological Aspects of Health Communication among Port Harcourt City Residents. An International Multidisciplinary Journal, Ethiopia, 2014. 8: 3.

Sack John. Operation Anaconda. Esquire. 2002. 138: 116123.

Sims Norman. The Literary Journalists. US: Ballantine Books, 1984.

Sims Norman. True Stories: A Century of Literary Journalism. Illinois: Northwestern University Press, 2007.

Sims Norman. The problem and the promise of literary journalism studies. Literary Journalism Studies. 2009. 1(1): 7-16.

Stewart J. John Sack. Dictionary of literary biography: American literary journalists, 1945-1995 / A. J. Kaul (Ed.). Detroit: Gale, 1997. pp. 273-282.

Whitt Jan. Women in American Journalism: A New History. University of Illinois Press, 2008.

Wolfe Tom. The New Journalism: With An Anthology. New York: Harper, 1973. pp. 31-33.

SKHID No. 3 (161) May-June 2019 
Eзеа Грегорі,

Університет Нігерії (Нсукка, Нігерія)

e-mail: Gregory.ezeah@unn.edu.ng,ORCID 0000-0002-0998-5251

Гевер Верлумун Селестін,

Університет Нігерії (Нсукка, Нігерія)

e-mail: Encyclopeadia100@gmail.com,ORCID 0000-0003-0618-5352

\section{ЛІТЕРАТУРНА ПУБЛІЦИСТИКА В УМОВАХ ГЛОБАЛЬНОїПРОДОВОЛЬЧОї КРИЗИ: ТЕХНІКИПОДОЛАННЯ}

Протягом багатьох років світові лідери продовжують розв'язувати питання боротьби з голодом. Хоча зростаючий голод впливає на країни різних континентів світу, африканські країни і частина Азії, здається, найбільше вражені цією проблемою. Це дослідження розглядає взаємозв'язок між літературною публіцистикою та боротьбою з глобальною продовольчою кризою, з фокусом на Нігерії. Зокрема, в дослідженні розглянуто ступінь розгортання літературної публіцистики для боротьби з голодом, техніки її розгортання 3 метою стимулювання державної політики щодо достатнього забезпечення продовольством та заохочення громадської участі в сільському господарстві. Попри те, що літературна публіцистика є новим жанром комунікацій в Нігерії, вона має потенціал сприяння сільськогосподарській діяльності та державній політиці із забезпечення продовольчої безпеки. Розуміння підходів і методів літературної публіцистики для боротьби з глобальною продовольчою кризою, по-перше, надає найновіші уявлення про роль публіцистики в розвитку сільського господарства та продовольчої безпеки; по-друге, сприяє розвитку і самого цього жанру, відкриваючи нові перспективи його вивчення. Міжнародний науково-дослідний інститут продовольчої політики у співпраці з Продовольчою та сільськогосподарською організацією у своєму Глобальному індексі голоду відніс Нігерію до країн 3 високим рівнем загрози голоду, з індексом 25,5 (серйозна загроза голоду). Базуючись на концепті "порушуваних правил" Марка Крамера, автори виділяють такі характеристики літературної публіцистики: занурення в світ історій; розробка неявних правил (завітів) щодо точності та щирості; опис головним чином повсякденних, рутинних подій; розвиток сенсу, заснованого на послідовній реакції читачів. У цьому дослідженні виникають наступні евристичні запитання: наскільки літературна публіцистика може сприяти продовольчій безпеці? Які методи літературної публіцистики можна використовувати для заохочення участі в сільському господарстві? Які методи літературної публіцистики можна використовувати для управління політикою та програмами уряду в сільському господарстві? Загалом 30 респондентів надали розповіді (наративи) про зв'язок між літературною публіцистикою та продовольчою достатністю. Як інструмент для збору даних використовувалось структуроване інтерв'ю, а для опрацювання результатів дослідження використовувався тематичний аналіз. Результат напівструктурованого інтерв'ю показав, що літературна публіцистика може допомагати у боротьбі 3 продовольчою кризою в усьому світі і в Нігерії. Також було виявлено, що методи, які використовуються для боротьби з продовольчою кризою, включають: сцену за сценою, інфотейнмент (комбінація інформації та розваг), діалог, суб'єктивність і точність. Під час інтерв'ю було виявлено, що літературна публіцистика не отримала належного місця в Нігерії, на відміну від інших країн, наприклад, Сполучених Штатів Америки, де вона практикується 3 1960-х років. Ці результати досліджувалися в рамках моделі ACADA (оцінка, комунікація, аналіз, дизайн, дії). Модель була розроблена Організацією Об'єднаних Націй для Міжнародного фонду надзвичайних ситуацій для дітей. Обговорювалися також можливості впливу отриманих результатів на достатнє забезпечення продуктами харчування та розширення ареалу дії літературної публіцистики.

Ключові слова: продовольча криза; голод; літературна публіцистика; техніки.

(c) Ezeah Gregory, Gever Verlumun Celestine

Надійшла до редакції: 22.04.2019

Прийнята до друку: 04.06.2019

СХІД № 3 (161) травень-червень 2019 р. 